\title{
An Empirical Study on College English Teacher's TPACK: Theory and Application
}

\author{
WEI Li, GAO Xia \\ Liaoning Police Academy, Dalian, China. Chuxiong Normal University, Chuxiong, China
}

\begin{abstract}
The article firstly reviews the development tendency and content of TPACK, which the product of close integration of subject content knowledge, pedagogical knowledge and technological knowledge. Then the author makes an analysis of the theoretical frameworks of TPACK and teachers' professional development. Experts have advanced various theoretical frameworks to analyze the content of TPACK from different theoretical orientations. The focus of this article lies in providing the design for college English teachers' professional training model of TPACK and making an empirical study on college English teachers' TPACK to put forward a couple of meaningful inspirations from the comparative study. It is of great value to guarantee that college English teachers can understand and grasp the contents of TPACK correctly and comprehensively, learning to carry out EFL teaching with advanced teaching concept and integrated modern technology.
\end{abstract}

Keywords-TPACK, EFL teaching, professional development, comparative study, integration

\section{INTRODUCTION}

The college English teacher's professional knowledge is the basis of teacher's specialization and the guarantee of conducting effective EGP teaching. In the teacher's specialized movement sprung up in $80 \mathrm{~s}$ of $20^{\text {th }}$ century, Shulman put forward the concept of Pedagogical Content Knowledge, claiming that the emphases on teachers' subject knowledge and pedagogy were being treated as mutually exclusive. He believed that teacher education programs should combine the two knowledge fields. Pedagogical knowledge means the "how" of teaching, generally acquired through education coursework and personal experiences. Content knowledge, on the other hand, is the "what" of teaching. It is different from the knowledge of a disciplinary expert and from general pedagogical knowledge. [1]The concept PCK was responded widely and accepted immediately after being put forth, becoming the most influencing theoretical framework for studying teacher knowledge and professional development. With the increasing connection between the information technology and education field, the traditional PCK framework cannot illustrate the necessary professional knowledge and attainment that the teachers possess to carry out effective teaching activity under information teaching environment. Many scholars proposed many a new theories and ideas to integrate information technology and subject teaching, such as Koehler and Mishra. They put forward Technological Pedagogical Content Knowledge which was approved and highly valued in no time.

TPACK is the product of close integration of subject content knowledge, pedagogical knowledge and technological knowledge; it's also the knowledge for the teacher to develop effective teaching under the concrete context with the characteristics of comprehensiveness, situation, dynamics, individuality, and practicalness. The effective college English teaching under the direction of TPACK framework is not the isolated application of technology into the original teaching mode and content, but the interactive coordination and highly integration of technology, subject content and teaching tact.

\section{THE ANALYSIS OF THEORETICAL FRAMEWORKS OF TPACK AND TEACHERS' PROFESSIONAL DEVELOPMENT}

\subsection{The composition of TPACK frameworks}

Experts have advanced various theoretical frameworks to analyze the content of TPACK from different theoretical orientations since the concept was put forward. [2]One of them is decomposing view which decomposes TPACK into several components. Koehler and Mishra are the most influential exerts who hold content knowledge, pedagogical knowledge and technological knowledge are three central elements of TPACK; pedagogical content knowledge, technological content knowledge, technological pedagogical knowledge, and technological pedagogical content knowledge are four compound elements. [3]The advantage of this theoretical orientation lies in its clear illustration of the holistic framework of TPACK contributing to understanding its complexity, while it also has its disadvantage in being unable to define each concept of TPACK and ravel out the interactive relations among different concepts. The other theoretical orientation is integrated view considering TPACK as a whole but not the component. The typical scholar is Niess who emphasizes four core elements: the holistic idea of integrating technology to teach specific subject, teaching strategy to apply technology to teach 
specific topic, curriculum to integrate subject and technology, knowledge that the students apply technology to comprehend, reflect on and learn. [4] The advantage of this framework consists in its integration and crossdisciplines examining relationships among subject, pedagogy, and technology from holistic perspective. This integrated view has powerful practical guiding significance in training pre-service and in-service teachers' TPACK capabilities.

\subsection{The professional development of teaching staff}

The professional development of a teacher is the professional growing process to improve teaching quality to make a well-deserved educator through professional training in the teaching career. Professor Ye Lan of East China Normal University believed that teacher's professional development is the teacher's professional growth or the continually updated, gradually processed, and enriched course of the teacher's inherently professional structure. [5] The contents of teacher's professional development generally compose professional knowledge, professional capabilities and professional affective. [6] Educational background upgrading, continuing education, refresher training and school-based teaching research and training are various approaches to realize teacher's professional development. To promote teacher's professional development is the worldwide mega trend of teachers' education, and also the urgent need and major countermeasure of our teaching faculty building.

\subsection{The relationship between TPACK and teachers' professional development}

The development of educational imformatization brings up the new demands for the knowledge structure and competence system of the future teachers. The capabilities in searching, applying and processing information, integrating information technology and curriculum, and directing the students to develop inquiry learning have become vital indicators to measure teachers' professional capability in the new era. This development displays many new characteristics and approaches. Teachers' professional development under the information technology has become the focus of research recently. Jiao Jianli argues that teachers' professional development under the support of information technology is to take information technology as environment, means, approach, way and method, being as a systematic, dynamic and complex process contributing to the improvement in professional knowledge, teaching skills and professional attitudes. [7]TPACK framework conforms to the demands of educational informatization, bring to the requirements of teachers' professional quality in the new age. The change of training ways and strategies provides new framework for the professional development. TPACK offers proper scheme to figure out the problem existed in the integrating class in digital age; it also offers new vision for re-orientating and developing teachers' professional quality.

\section{THE COMPARATIVE STUDY OF COLLEGE ENGLISH TEACHERS FOR TPACK KNOWLEDGE AND RESEARCH FINDINGS AND DISCUSSIONS}

\subsection{The design for college English teachers' professional training model in TPACK}

According to TPACK framework and its contents, we design a college English teachers' TPACK professional development model based on blended training concept. This blended training refers not only to faceto-face training, but also to the comprehensive network training. The model develops three-leveled holistic training from the perspective of 7 constituting elements of TPACK aimed at professional development and expected provisions. Fig. 1 presents the concrete illustration of this model.

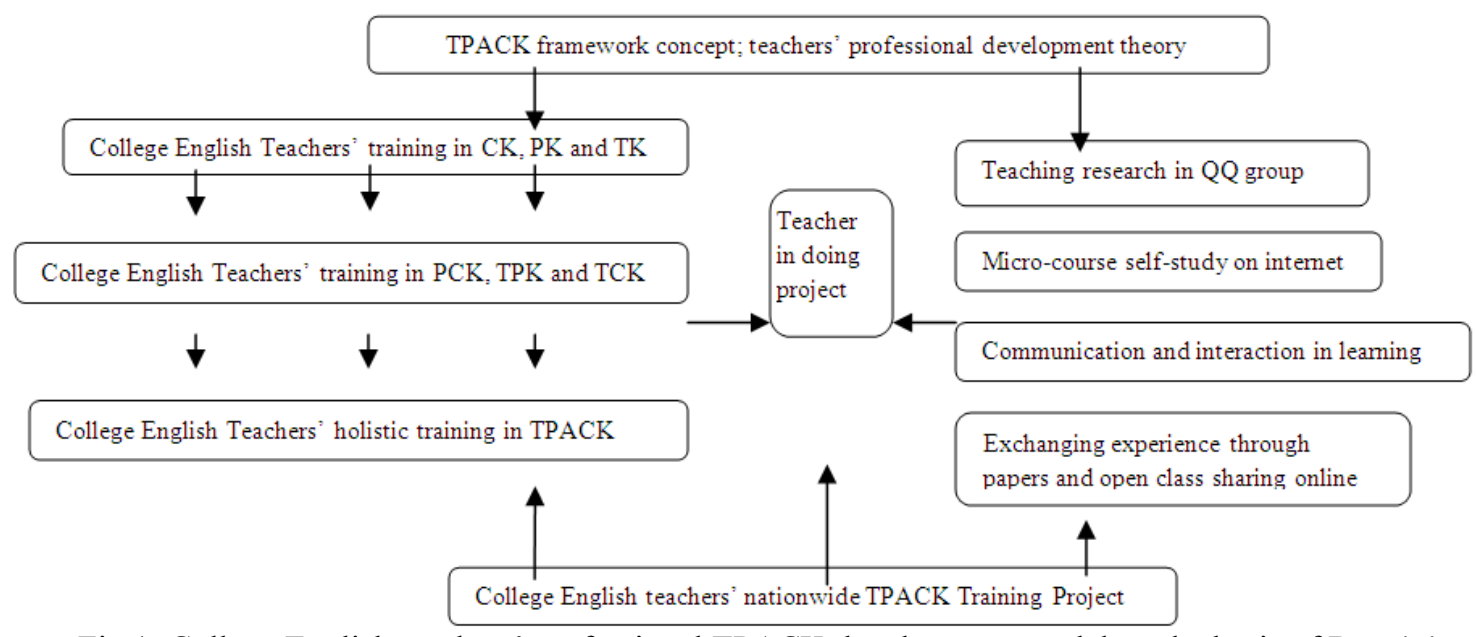

Fig 1: College English teachers' professional TPACK development model on the basis of B-training 


\subsection{The comparative study of college English teachers for TPACK knowledge in teaching practice}

TPACK, as the important representation of new type of teachers has such particular characteristics as context, implicitness and individuality. At the same time, because TPACK is difficult to perceive and present, with three factors (content, technology, and pedagogy) interacting together in dynamic way, we have to adopt the case study to explore the mastering condition of TPACK knowledge that college English teachers are equipped with. We select five English teachers from three universities and colleges to represent various professional titles, educational backgrounds, academic capabilities and achievements, years of teaching, teaching types, teaching objects, etc. Table 1 presents detailed information of 5 research subjects.

\begin{tabular}{|l|l|l|l|l|l|l|l|}
\hline $\begin{array}{l}\text { Teache } \\
\mathrm{r}\end{array}$ & $\begin{array}{l}\text { Educational } \\
\text { background }\end{array}$ & $\begin{array}{l}\text { Profession } \\
\text { al } \\
\text { title }\end{array}$ & $\begin{array}{l}\text { Teachi } \\
\text { ng } \\
\text { type }\end{array}$ & Teaching object & $\begin{array}{l}\text { Academic } \\
\text { level }\end{array}$ & $\begin{array}{l}\text { Years of } \\
\text { teaching }\end{array}$ & $\begin{array}{l}\text { Gende } \\
\mathrm{r}\end{array}$ \\
\hline No.1 & $\begin{array}{l}\text { B.A.in English } \\
\text { language\& } \\
\text { literature }\end{array}$ & Professor & $\begin{array}{l}\text { EGP } \\
\text { and } \\
\text { ESP }\end{array}$ & $\begin{array}{l}\text { Students of Police Academy } \\
\text { (Economic investigation major) }\end{array}$ & $\begin{array}{l}\text { A level } \\
\text { highest } \\
\text { level }\end{array}$ & 23 & male \\
\hline No. 2 & $\begin{array}{l}\text { M.A. in applied } \\
\text { linguistics }\end{array}$ & $\begin{array}{l}\text { Associate } \\
\text { professor }\end{array}$ & $\begin{array}{l}\text { English } \\
\text { culture }\end{array}$ & $\begin{array}{l}\text { Students of Normal University } \\
\text { (English major) }\end{array}$ & B level & 30 & female \\
\hline No. 3 & $\begin{array}{l}\text { M.A. in English } \\
\text { literature Associate } \\
\text { professor }\end{array}$ & EGP & $\begin{array}{l}\text { Students of comprehensive } \\
\text { university (Physics department) }\end{array}$ & C level & 23 & female \\
\hline No. 4 & $\begin{array}{l}\text { M.A. in English } \\
\text { testing Lecturer }\end{array}$ & $\begin{array}{l}\text { EGP } \\
\text { and } \\
\text { ESP }\end{array}$ & $\begin{array}{l}\text { Students of Police Academy } \\
\text { (Information technology major) }\end{array}$ & D level & 13 & female \\
\hline No. 5 & $\begin{array}{l}\text { A Ph.D. } \\
\text { candidate in } \\
\text { English literature }\end{array}$ & Lecturer & $\begin{array}{l}\text { EGP } \\
\text { and } \\
\text { ESP }\end{array}$ & $\begin{array}{l}\text { Students of Police Academy } \\
\text { (Economic investigation major) }\end{array}$ & E level & 15 & female \\
\hline
\end{tabular}

Table 1: Basic information statistics of 5 research subjects

The subjects' data and information derive from interview and classroom observation and investigation. The main interview contents cover the processing course, the current situation, characteristics, knowledge and concept of the technological application in EFL teaching. Through detailed analysis of the interview, we develop the comparative study of different cases to extract the significant findings relevant to this research.

\subsection{The findings and discussions of the comparative study}

The understanding about the integration of information technology and EFL teaching: 80 percent of subjects think that information technology promotes college English teaching, holding that it arouses students' learning interest, prolongs their attention span, enriches teaching contents and resources, provides much more English learning opportunities than traditional teaching method does, and creates after-class teaching and communicating platform. But some teachers claim that information technology should be used appropriately without replacing English teachers' guiding roles. The major role of information technology is to assist teacher in realizing perfect instructional design and finishing active teaching process.

These five subjects have different attitudes toward the functions and application of information technology in EFL teaching. No. 1 is the pioneer and advocator of applying information technology into his English teaching. He coined VPIE (Virtual Policing in English) and Virtual Service Learning pedagogies with research interest in web-mediated instructional technology. No. 2 thinks that it's enough to apply the basic technology in English teaching, for English teachers haven't professional background in computer science and they cannot break the technological bottleneck. In short, college English teachers have various understandings about the application of information technology. This reflects that teachers' concepts have characteristics of individuality and diversity which is relevant to teachers' time and energy, teaching understanding and input, and technological interests and knowledge.

Teaching strategies of integration of information technology and EFL teaching: among these five subjects, only No.1 holds that his grasp of information technology (through his own self-study in information science) can effectively cope with his teaching design and process. But other subjects agree that their informational technology is only at primary level, and they don't have much interest in improving technology with growing age.

Most of college English teachers don't take part in formal technological training and the training in computerassisted EFL teaching, so they can only use the technology at basic level, such as exploring teaching resources on internet, downloading and playing English video and audio, English songs, English comedy as lead in or listening materials, making Word documents or PowerPoint to present teaching focus, applying QQ group or WeChat group to share extracurricular teaching materials or answer students' questions. Although No. 1 apply internet to make the students fulfill virtual policing training and design scenario through virtual role playing, 
other subjects can only use information technology in surface level to realize the fundamental teaching functions. As a result, to realize the goal of college English teachers equipped with information technology and TPACK capabilities is a long and tough course from using SE and playing teaching resources to controlling net teaching platform and making teaching videos. Only through persistent lifelong learning and attempt at new technology can college English teachers update their concept and technological equipment to improve their ability in selecting, controlling, and assessing information technology in their EFL teaching.

\subsection{The significance and inspiration of the comparative study}

We can obtain some new points of views from this empirical study about TPACK survey. It's required that we should change training curriculum and focus for those students pursuing in normal university and inservice teachers. In the training of content pedagogy, the focus is to train TPACK content including EFL teaching design with information technology, high- quality teaching software making, the skillful use of webbased teaching platform, the construction of teaching repository, etc. It is necessary to guarantee that college English teachers can understand and grasp the contents of TPACK correctly and comprehensively, learning to carry out EFL teaching with integrated modern technology. It's proposed that we should construct college English teachers' learning community to promote TPACK sharing and communication. The effective external approaches to improve TPACK development are to watch excellent open class, visit and evaluate class, and develop teaching research projects together,

\section{CONCLUSION}

Although TPACK, as an integrated knowledge framework, has been advanced for a decade, it's really a difficult task to attain the goal of building college English teaching staff equipped with TPACK capabilities. Under the global background of flourishing educational informatization, the deep integration of information technology and foreign language curriculum is bound to be the tendency of EFL education. Admittedly, teacher is the dominant pushing force to urge teaching reform, and the ultimate goal of educational reform can be realized only when the teacher possesses the knowledge to carry out new teaching model supported by information technology. Consequently, the improvement of college English teachers' TPACK and professional development means much to promote in-depth integration of information technology into foreign language teaching.

\section{ACKNOWLEDGEMENTS}

The research is financed by College Teaching Reform Research Project of Liaoning Province (2014) No. UPRP20140574: Multi-Models to Develop College Students' 3C Abilities through Network College English Teaching and Learning Based upon Questions, and it is also financed by the Twelfth Five-year Plan for Educational Science Project of Liaoning Province (2015) No.JG15DB170: A Study on Self-regulated Microcourse Learning and Implicitly Layered English Flipped Classroom, and by the Foreign Language Teaching Reform and Research Important Project of Liaoning Higher Education Academy (2015) No.WYZD150013: The Deep Integration of SPOC of ESP and EGP.

\section{REFERENCES}

[1] Schulman, L.S., Those who understand: knowledge growth in teaching, Educational Researcher, 15(2), 1986, 4-14.

[2] Voogt, J., Fisser, P., Pareja Roblin, N., Tondeur, J., \& van Braak, J., Technological pedagogical content konwledge-A review of literature, Journal of Computer Assisted Learning, 29, 2013, 109-121.

[3] Koehler, M. J., Mishra, P., \& Yahya, K., Tracing the development of teacher knowledge in a design seminar: Integrating content, pedagogy, and technology, Computer \& Education, 49, 2007, 740-762.

[4] Niess, M., Preparing teachers to teach science and mathematics with technology: Developing a Technology Pedagogical Content Knowledge, Teaching and Teacher Education, 21, 2005, 509-523.

[5] Ye Lan, New Probe into teacher's roles and teacher's development, Beijing: Educational Science Press, 2001.

[6] Wang Jijun, Chen Lei, Li Xiaoqing, Xie Fei, Yang Jiqiong, Cao Peijie, Research on the Teachers' Professional Development in the Frontier Minority Areas from the Respective of TPACK, China Educational Technology, 5, 2015, 118-123.

[7] Jiao Jianli, TPACK: a framework of the integration of information technology and curriculum. http://jiao.blogbus.com/logs/36052058.html,2009-06-03. 